\title{
Role of serum magnesium in diabetes mellitus - A case control study
}

\author{
M. Girija Menon ${ }^{1}$, Amrut Arvindrao Dambal2,", D. Sridevi ${ }^{3}$, Harika Kolli ${ }^{4}$, G. Lakshmi Chaitanya ${ }^{5}$ \\ ${ }^{\mathbf{1}}$ Professor, Dept. of Biochemistry, Dr. Patnam Mahender Reddy General Hospital, Chevella, Telangana, ${ }^{\mathbf{2} 3}$ Associate Professor, \\ ${ }^{4}$ Assistant Professor, ${ }^{5}$ Tutor, Dept. of Biochemistry, Malla Reddy Institute of Medical Sciences, Hyderabad, Telangana, India
}

\section{*Corresponding Author: Amrut Arvindrao Dambal}

Email: dramrutdambal@gmail.com

Received: $4^{\text {th }}$ May, 2018

Accepted: $1^{\text {st }}$ June, 2018

\begin{abstract}
Introduction: Diabetes mellitus characterized by high glycemic levels is routinely associated with many mineral abnormalities. The purpose of this study was to evaluate the levels of serum magnesium among subjects with diabetes mellitus and to compare and analyze the same in normal non diabetics.

Materials and Methods: In this case control study conducted at Malla Reddy Hospital, 50 subjects known to be diabetics were considered as cases and 50 apparently normal non- diabetics were the controls. Serum magnesium was estimated, compared and analyzed.

Results: Serum magnesium levels were $1.89 \pm 0.32$ among cases and $2.26 \pm 0.27$ among controls. Extreme statistical significance was observed between both the groups.

Conclusion: Serum magnesium levels were found to be decreased in subjects with diabetes mellitus. We conclude that diabetes mellitus could influence magnesium homeostasis.
\end{abstract}

Keywords: Diabetes mellitus, Magnesium, Fasting plasma glucose.

\section{Introduction}

Diabetes mellitus, a common metabolic disorder is a major health problem that is approaching epidemic proportions globally. Worldwide, the prevalence of this chronic non-communicable disease is increasing at an alarming rate. ${ }^{1}$ Hyperglycemia in diabetes mellitus is known to have its effect on almost all body systems causing various structural and biochemical changes.

Diabetes mellitus characterized by high glycemic levels is routinely associated with many mineral abnormalities.

Magnesium, the second predominant component in the intracellular compartment is a critical cofactor for the activities of various enzymes involved in glucose oxidation and may play a role in the release of insulin. ${ }^{2}$ Magnesium is involved at multiple levels in insulin secretion, binding and activity. ${ }^{3}$ Literature has revealed that diabetes mellitus is associated with hypomagnesemia with prevalence of 25 to $39 \% .^{4-6}$ There is an association between hypomagnesemia and insulin resistance, carbohydrate intolerance, accelerated atherosclerosis, dyslipidemia, hypertension and adverse outcomes. ${ }^{6}$

Many studies have shown that both mean plasma and intracellular free magnesium levels are lower in patients with diabetes than in the general population. This magnesium deficiency, which may take the form of a chronic latent magnesium deficit rather than clinical hypomagnesemia, may have clinical importance because the magnesium ion is a crucial cofactor for many enzymatic reactions involved in metabolic processes. Many studies show that mean plasma levels are lower in patients with diabetes compared with nondiabetic control subjects. ${ }^{7}$
Resnick and associates suggest that extracellular and intracellular magnesium deficiency is typical in chronic, stable, mild type 2 diabetes and may be a strong predisposing factor for the development of the excess cardiovascular morbidity associated with diabetes. $^{8}$

The purpose of this study was to evaluate the levels of serum magnesium among subjects with diabetes mellitus and to compare and analyze the same in normal non diabetic subjects.

\section{Materials and Methods}

This case control study was taken up in Malla Reddy hospital, Hyderabad from October 2014 to August 2015. Ethical clearance was obtained from the Institutional Ethical Clearance Committee. 50 subjects who were diagnosed to be diabetics in the last 5 years and visiting the diabetic clinic in Malla Reddy hospital were considered as cases. 50 apparently normal non diabetic subjects were considered as controls. Detailed history and clinical examination and biochemical investigations including patients age, sex, duration of diabetes mellitus, details regarding presenting complaints, past history of any other diseases, history of co-morbid diseases like hypertension, ischemic heart disease, family history of diabetes and hypertension were taken.

Inclusion Criteria: All cases of Type 2 diabetes mellitus patients and non diabetic controls aged between 30 to 70 years attending diabetic clinic, at Malla Reddy hospital, Hyderabad.

\section{Exclusion Criteria:}

1. Patients with renal failure. 
2. Patients who suffered acute myocardial infarction in last six months.

3. Endocrinopathies, Patients on diuretics.

4. Patients with history of alcohol abuse.

5. Patients on magnesium supplements/magnesium containing antacids.

6. Mal absorption.

7. Chronic diarrhea which all affect magnesium homeostasis.

Venous blood samples were collected from the cases and controls. Blood was allowed to clot and serum was separated. Serum magnesium, fasting plasma glucose and postprandial plasma glucose were analyzed.

Method: Estimation was done by Glucose Oxidase Peroxidase for plasma glucose and Xylidyl Blue for serum magnesium in CPC Chemwell's general chemistry analyzer.

Mean and standard deviation were calculated for the above parameters among cases and controls. Student ' $t$ ' test was applied. Fasting plasma glucose and post prandial plasma glucose were correlated with serum magnesium among cases. Statistical analysis was done using SPSS package version 20. Statistical significance was calculated using $\mathrm{p}$ value.

\section{Results}

In this study of 100 subjects, 50 were cases and 50 were controls. The normal reference range for serum magnesium was $1.7-2.9 \mathrm{mg} / \mathrm{dl}$.

In this study the mean age of cases and controls were $44.72 \pm 2.16$ and $45.35 \pm 1.98$ respectively. This was an age matched study with no statistical significance between both the groups $(\mathrm{P}=0.13)$ [Table 1, Fig. 1].

Among the cases, 31 were males and 19 were females and among controls, 33 were males and 17 were females [Table 2, Fig. 2].

In this study, the serum magnesium levels were in the range between 1.61 and 2.15 with Mean \pm SD being $1.89 \pm 0.32$ among cases. So also the study showed that the serum magnesium levels were in the range between 2.07 and 2.56 with Mean \pm SD being $2.26 \pm 0.27$ among controls. Extreme statistical significance was observed between both the groups.

Mean fasting plasma glucose among cases and controls were $131.8 \pm 10.66$ and $95.01 \pm 6.89$.

Mean post prandial plasma glucose among cases and controls were $187.13 \pm 21.63$ and $129.34 \pm 9.42$.

A negative correlation was observed between fasting plasma glucose and serum magnesium $(\mathrm{r}=$ 0.24 ) among cases. A weak positive correlation was observed between post prandial plasma glucose and serum magnesium $(\mathrm{r}=0.018)$ among cases. (Table 3)

Table 1: Comparison of age and serum magnesium between cases and controls

\begin{tabular}{|l|c|c|c|}
\hline & Cases & Controls & P Value \\
\hline Age & $44.72+2.16$ & $45.35+1.98$ & $\mathrm{P}=0.13$ \\
\hline Serum magnesium & $1.89 \pm 0.32$ & $2.26 \pm 0.27$ & $\mathrm{P}<0.0001^{*}$ \\
\hline
\end{tabular}

*Extremely Significant

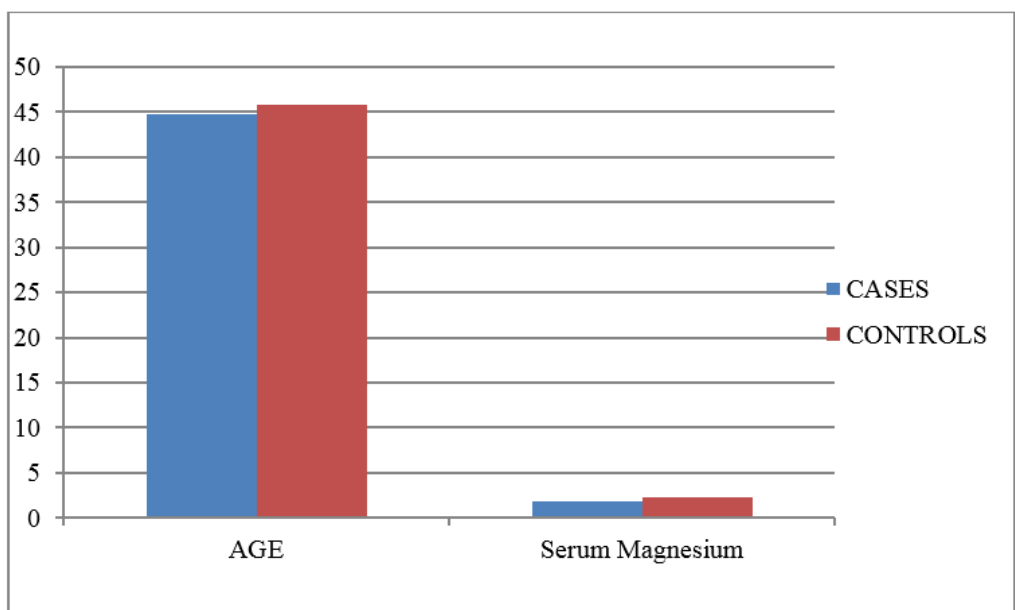

Fig. 1: Comparison of age and serum magnesium between cases and controls

Table 2: Comparison of gender among cases and controls

\begin{tabular}{|l|c|c|}
\hline & Males & Females \\
\hline Cases & 31 & 19 \\
\hline Controls & 33 & 17 \\
\hline
\end{tabular}




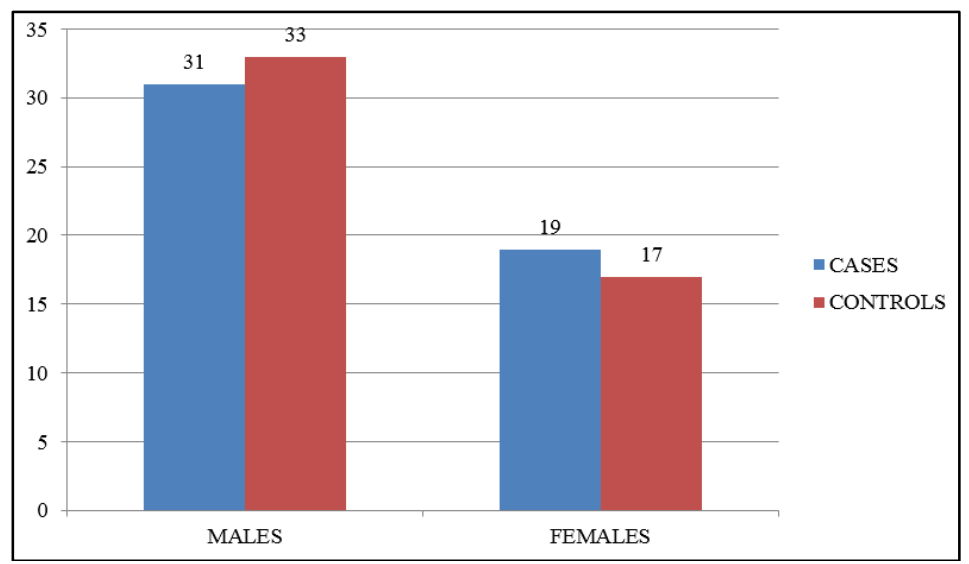

Fig. 2: Comparison of gender among cases and controls

Table 3: Correlation of serum magnesium with fasting plasma glucose and post prandial plasma glucose among cases

\begin{tabular}{|l|c|c|}
\hline & & r Value \\
\hline \multirow{3}{*}{$\begin{array}{l}\text { Serum Magnesium(mg/dl) } \\
1.89 \pm 0.32\end{array}$} & Fasting Plasma Glucose $(\mathrm{mg} / \mathrm{dl})$ & $-0.24^{*}$ \\
\cline { 2 - 3 } & $131.82 \pm 10.66$ & 0.018 \\
& Post Prandial Plasma Glucose $(\mathrm{mg} / \mathrm{dl})$ & \\
\hline
\end{tabular}

*Negative correlation

\section{Discussion}

Diabetes, a major non communicable pandemic disease, is routinely associated with imbalance in mineral homeostasis.

Magnesium, the second most common intracellular cation has a fundamental role in many enzymatic reactions involving energy metabolism. As per literature serum magnesium has been found to be low or decreased in major endocrine and metabolic disorders, diabetes being one of the commonest.

Magnesium $(\mathrm{Mg})$ is a vital trace element required for glucose homeostasis and glucose metabolisms as a complex interplay exists in between them. $\mathrm{Mg}$ is involved in functioning of various enzymes which are required for glucose oxidation, and release of insulin. ${ }^{9-}$ ${ }^{11}$ Insulin stimulates the uptake of $\mathrm{Mg}$ intracellular. ${ }^{12}$ Magnesium deficiency may result in disorders of tyrosine kinase activity on the insulin receptor, event related to the development of post-receptoral insulin resistance and decreased cellular glucose utilization that is, the lower the basal $\mathrm{Mg}$, the greater the amount of insulin required to metabolize the same glucose load, indicating decreased insulin sensitivity. ${ }^{13}$ The deficiency of Magnesium tend to alter the activity of membrane bound $\mathrm{Na}+\mathrm{K}+-$ ATPases, ${ }^{14}$ which play a role in glucose transport by providing $\mathrm{Na}+$ and $\mathrm{K}+$ ions. ${ }^{15,16}$

In this age and sex matched case control study, serum magnesium levels were found to be on the lower side of normal range in comparison to the controls.

Our study is in accordance with Rude $\mathrm{RK}^{5}$ who observed that osmotic diuresis clearly accounted for a portion of magnesium loss. Glycosuria which accompanies the diabetic state impairs renal tubular reabsorption of magnesium from the glomerular filtrate.

Garland ${ }^{17}$ stated that Hypomagnesemia in diabetes is mainly due to a reduction in tubular reabsorption.

Sales $\mathrm{CH}$ et $\mathrm{al}^{18}$ states that low serum magnesium levels are frequently present in diabetics and can be a cause for chronic complications to appear precociously. However our study is not in accordance with the study by Zagar et al who observed there is no influence of diabetes mellitus on serum magnesium concentration. ${ }^{11}$

In this study a negative correlation was observed between fasting plasma glucose and serum magnesium among the cases. Our study is in accordance with Shaikh MK et al who stated that hyperglycemia is inversely related to Hypomagnesemia in patients with type 2 diabetes. ${ }^{19}$

Negative correlation of fasting plasma glucose with serum magnesium among cases was also in accordance with studies which stated that $\mathrm{Mg}$ depletion has a negative impact on glucose homeostasis and insulin sensitivity in diabetic patients ${ }^{20,21}$ as well as on the evolution of complications such as retinopathy, thrombosis and hypertension. ${ }^{22-24}$

Paolisso et $\mathrm{al}^{25}$ suggests that low serum magnesium can be an aetiological factor for diabetes as it diminishes tyrosine kinase activity and impairs usage of intracellular glucose.

Delva et $\mathrm{al}^{26}$ states, cellular ionic alterations in diabetes lead to increased cellular ATP concentration that may result in decrease of intracellular magnesium.

Studies have revealed that insulin regulates intracellular magnesium concentration by stimulating 
the plasma membrane ATPase pump. ${ }^{27}$ Magnesium deficiency may be a consequence of insulin resistance.

Insulin resistance could be a factor for decreased serum magnesium levels by dysregulating intestinal absorption, uptake and mobilization of bone magnesium and renal excretion. ${ }^{28}$

Extracellular and intracellular magnesium deficiency is typical in chronic, stable, mild type 2 diabetes and may be a strong predisposing factor for the development of the excess cardiovascular morbidity associated with diabetes. ${ }^{8}$

\section{Conclusion}

In the present study serum magnesium levels were found to be decreased in subjects with diabetes mellitus. Hence we conclude that diabetes mellitus could influence magnesium homeostasis which may be the reason for low serum magnesium levels and it could be one among the risk factors for chronic complications in future.

\section{References}

1. Marwa AT, Amar MI. Evaluation of Calcium, Phosphorus and Magnesium Level Among Vitamin D Deficient Diabetes Mellitus Patients in Khartoum State. Scholars Bulletin. 2015;1(9):235-241.

2. Hans CP, Sialy R, Bansal DD. Magnesium deficiency and diabetes mellitus. Current science. 2002;83(12):1458 1463.

3. Garfinkel D. Magnesium. 1988;7:249-261

4. Mooradian AD, Morley JE. American journal of clinical nutrition. 1987;45:877-895.

5. Rude RK. Postgraduate medicine. 1992; 92: 217-224

6. Resnick LM, Gupta RK, Bhargava KK, Hgruenspan H, Alderman MH, Laragh J. Hypertension. 1991;17:951957.

7. Kulkarni AG, Shendge SK, Shinde V. Study of Serum Magnesium Levels in Types 2 Diabetes Mellitus. IOSR Journal of Dental and Medical Science. 2014;13(4):115119.

8. Resnick LM, Altura BT, Gupta RK, Larsh JH, Alderman MH, Altura BM. Intracellular and extracellular magnesium depletion in type 2 diabetes mellitus. Diabetologia. 1993;36:767-770.

9. Yajnick CS, Smith RF, Hockaday TDR and Ward NL. Fasting plasma magnesium concentrations and glucose disposal in diabetes. BMY. 1984;288:1032-1034.

10. Goldman $\mathrm{J}$ and Fisher V, Magnesium is required in addition to calcium for insulin stimulation of glucose transport. Endocrinology. 1983;112:271.

11. Zargar AH, Shah NA, Masoodi SR, Laway BA, Dar FA, Khan AR, Sofi FA and Wani AI. Copper, zinc, and magnesium levels in non-insulin dependent diabetes mellitus. Postgrad Med J. 1998;74(877):665-68

12. Viktorinova A, Toserova E, Krisko M and Durackova Z. Altered Metabolism of Copper, Zinc, and Magnesium is Associated with Increased levels of Glycated Hemoglobin in patients with Diabetes Mellitus. Metabolism. 2009;58(10):1477-82.

13. Parlapally RP, Rajini Kumari K, Aruna Jyothi S. Serum Magnesium Levels in Type 2 Diabetes Mellitus. International Journal of Scientific Study: 2016;4(5):176179.
14. Kareem I., Jaweed S.A., Bardapurkar J.S. and Patil V.P, Study of Magnesium, Glycosylated Hemoglobin and Lipid Profile in Diabetic Retinopathy. Indian. Journal of Clinical Biochemistry. 2004;19(2):124-27

15. Durlach J, Altura, and Altura B.M, Highlights and summary of the 10th Annual French Colloquium on Magnesium. Magnesium.1983;2:330-36.

16. Molitoris B.A, Acute kidney injury. Cecil Medicine. 2007;23rd ed: 121 .

17. Garland HO. Magnesium Research. 1992;5:193-202S

18. Sales CH, Pedrosal DF. Clinical Nutrition. 2006;25(4):554-562.

19. Shaikh MK, Devrajani BR, Soomro AA, Ali Shah SZ, Devrajani T and Das T. Hypomagnesemia in Patients with Diabetes mellitus. World Applied Sciences Journal. 2011;12(10):1803-1806.

20. Durlach J, Rayssiguier Y. Données nouvelles sur les relationsentre magnésium et hydrates de carbone. Magnesium. 1983;2:192-224.

21. Nadler J L, Buchanan T, Natarajan R, Antonipillai I, Bergman R, Rude R. Magnesium deficiency produces insulin resistance and increased thromboxane synthesis. Hypertension. 1993;21:1024-9.

22. Mather H M, Levin GE, Nisbet JA. Hypomagnesemia and ischemic-heart-disease in diabetes. Diabetes Care. 1982;5:452-3.

23. McNair P, Christiansen C, Madsbad S, Lauritzen E, Faber $\mathrm{O}$, Binder $\mathrm{C}$, et al. Hypomagnesemia, a risk factor in diabeticretinopathy. Diabetes. $1978 ; 27: 1075-7$.

24. Nadler J L, Malayan S, Luong H, Shaw S, Natarajan RD, Rude R K. Intracellular free magnesium deficiency plays a key role in increased platelet reactivity in type II diabetes mellitus. Diabetes Care. 1992;15:835-41

25. Paoliss G, Barbagallo M. Hypertension, Diabetes Mellitus and insulin resistance, the role of intracellular magnesium. American journal of Hypertension. 1997;10(3):346-355.

26. Delva P, Degan M, Pastori C, Faccini G, Lechi A. Glucose induced alterations of intracellular ionized magnesium in human lymphocytes. Life Science. 2002;71:2119-2135.

27. Olefsky J M, Nolam J J. American journal of clinical Nutrition. 1995;61:980-986

28. Shills M E. Annual review of nutrition. 1988;8:429-460.

How to cite this article: Menon M. G, Dambal A. A, Sridevi D, Kolli H, Chaitanya G. L. Role of serum magnesium in diabetes mellitus - A case control study. Int $\mathrm{J}$ Clin Biochem Res. 2018;5(4):505-508. 